RESEARCH ARTICLE

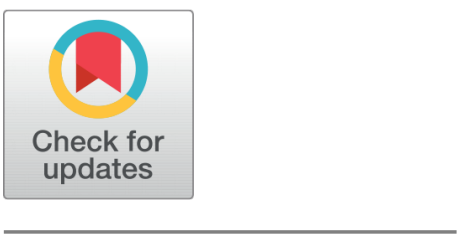

open acCess

Received: 23.07.2020

Accepted: 12.01 .2021

Published: 27.01.2021

Citation: Deebika P, Merline Sheela A, llamathi R (2021) Biochar and compost-based phytoremediation of crude oil contaminated soil. Indian Journal of Science and Technology 14(3): 220-228. https://doi.org/ 10.17485/IJST/v14i3.1178

* Corresponding author.

Tel: + 919884216255

merline@annauniv.edu

Funding: None

Competing Interests: None

Copyright: (c) 2021 Deebika et al. This is an open access article distributed under the terms of the Creative Commons Attribution License, which permits unrestricted use, distribution, and reproduction in any medium, provided the original author and source are credited.

Published By Indian Society for Education and Environment (iSee)

ISSN

Print: 0974-6846

Electronic: 0974-5645

\section{Biochar and compost-based phytoremediation of crude oil contaminated soil}

\author{
P Deebika ${ }^{1}$, A Merline Sheela1*, R Ilamathi ${ }^{1}$ \\ 1 Centre for Environmental Studies, Anna University, Chennai, 600025, Tamil Nadu, India. \\ Tel.: + 919884216255
}

\section{Abstract}

Objectives: To study the effect of compost and biochar on phytoremediation of crude oil-contaminated soil. Methods: An attempt was made to remediate crude oil contaminated soil, using the phytoremediation method. The soil was amended with biochar and compost. Initially, the $\mathrm{pH}$, moisture content and $\mathrm{C} / \mathrm{N}$ ratio of the soil and amendments were determined. A pot culture experiment was conducted to study the effect of the amendments on the degradation of the Total Petroleum Hydrocarbons (TPH) in the crude oil contaminated soil using the plant species nutgrass (Cyperus rotundus). To avoid seepage of water from the pots plastic pots were used. The initial concentration of TPH was found to be $17 \mathrm{mg} / \mathrm{kg}$ soil. The experiment was conducted from January to March 2019. No microorganism was inoculated either to enhance the growth of the plant or degrade the hydrocarbon. The study was conducted with natural microflora. The pots were kept (open) under direct sunlight with 8 hours of photoperiodism. The plants were watered daily with tap water to maintain optimum moisture content. Once in 15 days, the soil samples collected from each treatment were analysed for $\mathrm{pH}$, moisture content and $\mathrm{C} / \mathrm{N}$ ratio. The TPH removal rate was determined for the $45^{\text {th }}$ day and $60^{\text {th }}$ day. Findings: The soil amended with compost ( $200 \mathrm{~kg} / \mathrm{soil})$ and biochar ( $50 \mathrm{~kg} / \mathrm{soil}$ ) enhanced the degradation of TPH by the plant species. The highest degradation percent of 62.2 and $77.1 \%$ was achieved on $45^{\text {th }}$ and $60^{\text {th }}$ day respectively in the treatment T5 (amended with biochar and compost). Further, there was an increase in shoot length $(54.52 \mathrm{~cm} /$ plant), root biomass $(0.74 \mathrm{~g} / \mathrm{plant})$ and shoot biomass $(5.08 \mathrm{~g} /$ plant) of the plants in the biochar and compost amended soil which was comparable with the results of the treatment $\mathrm{T} 2$ (Plants were grown in soil without crude oil contamination). Applications: Biochar and compost amendment improves the water holding capacity and nutrient status of the soil, thereby enhancing the growth of TPH degraders in soil. Hence, from the study, it is understood that biochar and compost could be used for phytoremediation of crude oil contaminated soils.

Keywords: Amendments; degradation of TPH; nutgrass 


\section{Introduction}

Crude oil pollution to agricultural soil is a global problem ${ }^{(1)}$. The soil contamination with crude oil pollution is considered an important issue because it destroys the soil structure, biodegradability and results in serious health hazards when exposed to the environment ${ }^{(2)}$. Due to contamination, the soil's physical and chemical properties such as soil moisture content, hydraulic conductivity, Atterberg units, Total organic carbon, total nitrogen and available phosphorus are affected ${ }^{(3)}$. Further, these pollutants are present in the environment for a long time due to the non - biodegrdable nature. Many physical and chemical methods are followed to remediate the crude oil polluted soil ${ }^{(4)}$. Conventional physical and chemical technologies for petroleum hydrocarbon remediation involve excavation, air sparging, removal and off-site treatment in biopiles, pump and treat, incineration, slurry and solid phase reactors, soil washing, soil vapour - extraction, asphalt batching, thermal desorption, chemical oxidation, hydrolysis and photolysis ${ }^{(5)}$. But the efficiency and adoptability of these methods are limited because of high cost and non-environmental friendly ${ }^{(6)}$. However, remediating such contaminated soils by bioremediation is the globally accepted approach due to the cost-effectiveness and environmentally friendly nature ${ }^{(7)}$. Furthermore, the incorporation of organic amendments including coir pith, poultry droppings, cow dung, rice husk to the hydrocarbon contaminated soil to enhance the biodegradation of pollutants ${ }^{(8-11)}$.In addition, along with biological processes, some additional methods such as chemical oxidation ${ }^{(12)}$ and surfactant enhancement ${ }^{(13)}$ were used to remediate crude oil-contaminated soil. On the other hand, biochar application is an alternative method to remediate crude oil pollution in soil, due to the benefits such as improving soil moisture retention, structure, microbial activity and plant growth ${ }^{(14)}$. It has been reported that crude oil contaminated soil was remediated efficiently with biochar obtained from rice straw ${ }^{(15)}$. However, plants play a crucial role in the toxic pollutants in the soil and the hydrocarbons present in crude oil contaminated soil is degraded using plant species such as nutgrass (Cyperus rotundus $)^{(16)}$ and Mimosa pudica ${ }^{(17)}$, $4^{\prime}$ 'lock plant (Mirabilis jalapa L. ${ }^{(18)}$, mesquite ${ }^{(19)}$ and forest tree species teak (Tectona grandis $)^{(20)}$. However, it is advantageous to use grass species for remediation studies due to the extensive fibrous root system with a huge surface area. Moreover, efficient degradation is achieved when nutrients are supplemented to the plant species used for remediation studies ${ }^{(21)}$. The plant species should grow well in the crude oil-contaminated soil. It is found that the nutgrass (Cyperus rotundus) has the potential to grow well in the contaminated sites. Hence, the present study was conducted with the objective of treating crude oil contaminated soil using the grass (Cyperus rotundus) supplemented with biochar and compost.

\section{Materials and Methods}

\subsection{Collection of samples}

The soil used for the study was collected from the garden of Anna University campus, Chennai, India $\left(13^{\circ} 00^{\prime} 39.19^{\prime \prime} \mathrm{N}\right.$ and $\left.80^{\circ} 14^{\prime} 54^{\prime \prime} \mathrm{E}\right)$. The region was not having a prior history of hydrocarbon contamination. Soil samples were collected from $15 \mathrm{~cm}$ depth using a spade. The clumps were broken to homogenize, air-dried, sieved using $<2 \mathrm{~mm}$ mesh and used for further study.

The biochar used for the study was obtained from Aura Biotechnologies Private Limited, Chennai, Tamil Nadu. Compost was purchased from the micro composting facility, Anakaputhur Municipality, Chennai, Tamil Nadu. The plant species nutgrass (Cyperus rotundus) was collected from a nearby area. Before conducting the experiment, the plants were grown in normal soil for 30 days.

\subsection{Characterization of samples}

The soil, biochar and compost were characterized based on ${ }^{(22)}$ for $\mathrm{pH}$, Moisture content and $\mathrm{C} / \mathrm{N}$ ratio. To measure the $\mathrm{pH}$ of soil and biochar a solution was prepared using distilled water (1:2.5 soil/biochar: water). The compost solution (1:10 compost: water) was prepared, thoroughly shaken in an orbital shaker at $160 \mathrm{rpm}$ for $30 \mathrm{~min}$. Then the $\mathrm{pH}$ was measured using $\mathrm{pH}$ metre (Elico LI 120) equipped with a combined glass - calomel electrode).

\subsection{Total hydrocarbon content in the soil}

Residual oil in soil was extracted using the conventional Soxhlet extraction method ${ }^{(23)}$. About $15 \mathrm{~g}$ of dry soil was placed in a cellulose thimble mixed with $2 \mathrm{~g}$ anhydrous Magnesium sulfate to remove the moisture. The thimble and its contents were extracted with dichloromethane for $16 \mathrm{~h}$ in a Soxhlet apparatus. The extraction efficiency of oil from soil was calculated using the formula

$$
\text { Oil yield }=(\text { weight of oil extracted/weight of soil }) \times 100
$$


The extract was condensed to $1 \mathrm{ml}$ in a rotary evaporator and fractionated by silica-gel column chromatography to separate the different fractions of crude oil. The components of hydrocarbons in extracted oil were analyzed by GC-MS (Agilent 6890NGC equipped with MS, GC column (DB-5MS $3 \times 0.25 \mathrm{~mm}$ and $0.25 \mu \mathrm{m}$ ).

\subsection{Pot culture studies}

In order to study the efficiency of the plant species to degrade the hydrocarbon present in the soil, a pot culture study was conducted. Uniform sized plastic pots (upper outer diameter $18 \mathrm{~cm}$, upper inner diameter $16 \mathrm{~cm}$, lower diameter $9 \mathrm{~cm}$ and height $15 \mathrm{~cm}$ ) were used. Each pot was filled with $1.0 \mathrm{~kg}$ of garden soil (unsterilized) collected from Anna University campus, Tamil Nadu, India. The experiment was conducted with the following treatments. For each treatment, three replications were maintained.

T1 - Soil (with crude oil contamination and without plant)

T2 - Soil (without crude oil contamination) + plant

T3 - Soil (with crude oil contamination) + plant + biochar

T4 - Soil (with crude oil contamination) + plant + Compost

T5 - Soil (with crude oil contamination) + plant + biochar + compost

The soil was contaminated with crude oil ( $5 \%$ volume/weight basis). Biochar and compost incorporated into each pot were 50 and $200 \mathrm{~g}$ respectively. For reference, a treatment with soil (without crude oil contamination) was maintained. Each pot was provided with an outlet hole at the bottom and kept on separate trays. The plants already grown in normal soil were uprooted carefully and planted in the pots. Uniform sized plants were selected and planted in the pots and each pot three plants were maintained. The pots were kept open under direct sunlight to get adequate light. To prevent damage caused by rodents, protective fencing was provided. The pots were irrigated daily. In order to avoid seepage of water from the pots, plastic containers were used. The drained water from the pots was collected using plastic plates kept at the bottom of each pot. The collected water was used for irrigation. The experiment was conducted with a field capacity of $60 \%$.

\subsection{Plant growth parameters}

The plant growth parameters such as shoot length shoot biomass and shoot biomass were determined on the $60^{\text {th }}$ day. The shoot length was measured from the soil surface to the point where the last leaf left the stem. The shoot and root biomass was determined by drying in a hot air oven at $85 \pm 5^{\circ} \mathrm{C}$ for eight hours. The oven-dry weight was recorded for biomass production,

\subsection{Effect on $\mathrm{pH}$, moisture content and $\mathrm{C} / \mathrm{N}$ ratio}

At the end of each week, the $\mathrm{pH}$ of the soil samples from the pots of the different treatments was determined. The moisture content and the $\mathrm{C} / \mathrm{N}$ ratio were observed in 15 days interval. The TPH content was determined on $0^{\text {th }}, 45^{\text {th }}$ and $60^{\text {th }}$ day.

\subsection{Removal of TPH from soil}

The soil samples collected from the pots were analyzed for the TPH content. From this, the \% removal was calculated using the formula

$$
\% \text { Removal }=\frac{A 2-A 1}{A 2} \times 100
$$

Where

$\mathrm{A}_{2}$ and $\mathrm{A}_{1}$ represent TPH concentration in $\mathrm{mg} / \mathrm{kg}$ before and after remediation

\section{Results and Discussion}

\subsection{Characteristics of soil, biochar and compost}

The soil used for the pot culture study, the biochar and the compost were characterized and the results are presented in Table 1.

The $\mathrm{pH}$ of the soil, compost and biochar was found to be 6.6, 6.8 and 7.1 respectively. Among the materials tested the $\mathrm{pH}$ of the biochar was observed to be 7.1 . The highest moisture content of $54 \%$ was expressed by compost. However, the moisture content of the biochar was found to be $19.8 \%$. There was not much variation in $\mathrm{C} / \mathrm{N}$ content of the materials and it ranged from 25 to $28 \%$. 
Table 1. Characteristics of soil, compost and biochar

\begin{tabular}{lllll}
\hline \multirow{2}{*}{ S.No } & \multirow{2}{*}{ Sample } & \multicolumn{3}{c}{ Parameters } \\
\cline { 3 - 5 } & & $\mathrm{pH}^{*}$ & Moisture Content $(\%)^{*}$ & $\mathrm{C} / \mathrm{N} \mathrm{ratio}^{*}$ \\
\hline 1$)$ & Soil & 6.6 & 27.2 & 25 \\
$2)$ & Compost & 6.8 & 54.0 & 27 \\
$3)$ & Biochar & 7.1 & 19.8 & 28 \\
\hline
\end{tabular}

* Values represent mean of three determinations

\subsection{Effect of crude oil contamination on soil characteristics}

After planting the pots with nutgrass (Cyperus rotundus), (the plants are having a fibrous root system and capable of establishing soils highly polluted with petroleum hydrocarbons) the $\mathrm{pH}$ of the soil was determined up to 8 weeks and the results are furnished in Figure 1.

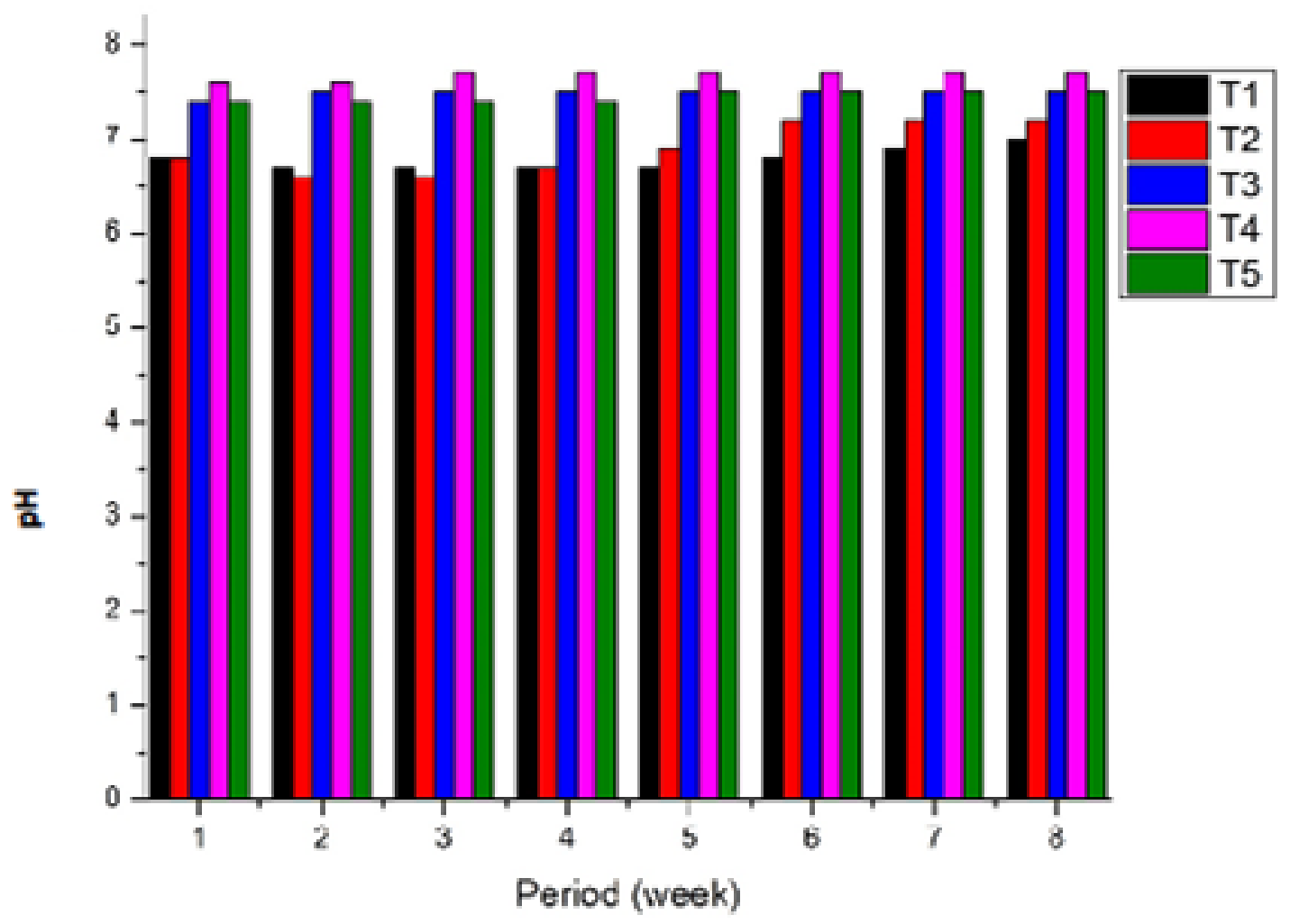

Fig 1. Effect of compost and biochar on $\mathrm{pH}$ of crude oil contaminated soil planted with Cyperus rotundus (Values are mean ofthree replications) (T1 - Soil (with crude oil contamination and withoutplant), T2 - Soil (without crude oil contamination) + plant, T3 - Soil (withcrude oil contamination) + plant + biochar,T4 - Soil (with crude oilcontamination) + plant + Compost, T5 - Soil (with crude oil contamination) + plant + biochar + compost) 
The $\mathrm{pH}$ of the soil collected from T1 (soil without crude oil contamination and plant) was found to be 6.8 to 7.0 for various time intervals. The treatment T2 (without crude oil contamination and with plants) showed pH values of 6.8 to 7.2. Last three weeks the $\mathrm{pH}$ was found to be 7.2. Likewise, the $\mathrm{pH}$ of the soil in T3 (Crude oil contaminated soil incorporated with biochar and with plants) was observed to be 7.4 for the initial two weeks and 7.8 afterward. In T4 (soil with crude oil contamination and incorporated with compost and with plants), initially, the $\mathrm{pH}$ was 7.3 and from the fourth week onwards, it was 7.7. The same trend was noticed in T5 (crude oil contaminated soil, incorporated with biochar, compost and with plants) (initial four weeks the $\mathrm{pH}$ was 7.4 and afterward, it was 7.5).

The moisture content of the soil in various treatments was determined and the results are presented in Figure 2.

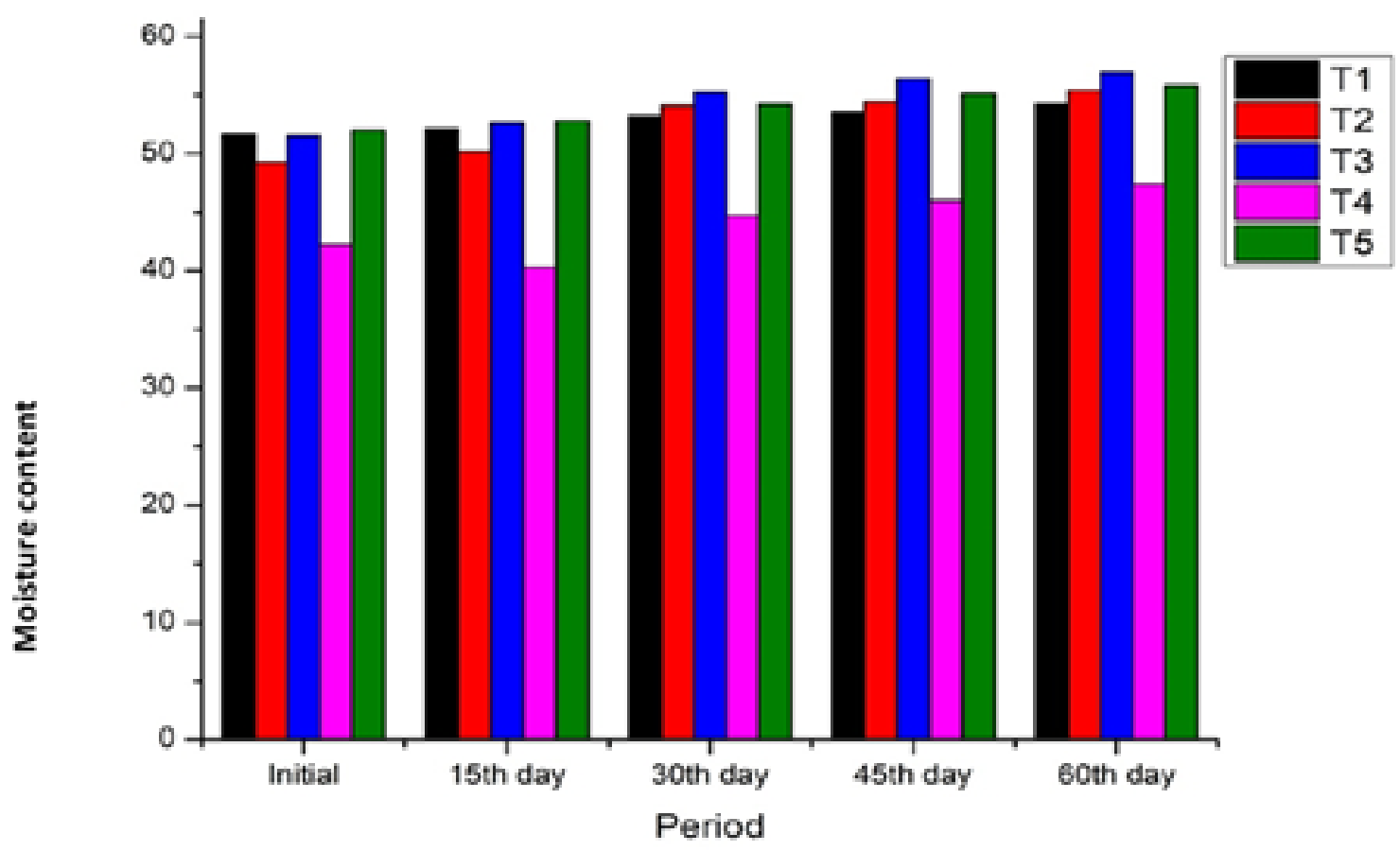

Fig 2. Effect of compost and biochar on moisture content of crude oil contaminated soil planted with Cyperus rotundus (For each treatment three replications weremaintained) (T1 - Soil (with crude oil contamination and without plant), T2 - Soil (without crude oil contamination) + plant, T3 - Soil(with crude oil contamination) + plant + biochar,T4 - Soil (with crude oil contamination) + plant + Compost, T5 - Soil (with crude oil contamination) + plant + biochar + compost)

The initial moisture content of the soil in T1, T2, T3, T4 and T5 was 51.6\%, 49.3\%, 51. 5\%, 42.3\% and 52.0\% respectively. On the $15^{\text {th }}$ day, it was observed to be $52.1,50.2,52.6,40.3$ and $52.8 \%$ for T1, T2, T3, T4 and T5 respectively. The moisture content of the soil samples on the 30 th day $(53.2,54.1,55.2,44.7$ and $54.2 \%), 40^{\text {th }}$ day $(53.5,54.4,56.4,46.0$ and $55.1 \%)$ and $60^{\text {th }}$ day (54.2, 55.4, 56.9, 47.4 and $55.8 \%)$ for $\mathrm{T} 1, \mathrm{~T} 2, \mathrm{~T} 3$ and $\mathrm{T} 4$ respectively.

The $\mathrm{C} / \mathrm{N}$ ratio was found to be $27,27,31,28$, and 29 (initial), $28,25,30,29,30$ ( $15^{\text {th }}$ day), $29,26,32,30$ and 31 ( $30^{\text {th }}$ day), 30 , $28,34,31$ and $32\left(45^{\text {th }}\right.$ day) and $31,29,35,32$ and $33\left(60^{\text {th }}\right.$ day) for T1, T2, T3, T4 and T5 respectively (Figure 3). Plant species are employed for the removal of petroleum hydrocarbon compounds from the soil which is achieved by physiological processes of plants and microbiological processes in the rhizosphere ${ }^{(24)}$. In the present study, the grass species (Cyperus rotundus) was used to remediate crude oil contaminated soil which was supplemented with biochar and compost. It has been investigated that amendments are added to the soil to enhance the microbial activity and biodegradation of pollutants in soil ${ }^{(25)}$. On the other hand, organic matter is added to the soil to improve the soil characteristics including water holding capacity ${ }^{(26)}$. Soil 
moisture content is an important factor to remediate toxic compounds in soil ${ }^{(27)}$ because water helps to increase the solubility of the compound thereby increasing the adsorption and degradation of pollutants within the plants. However, in crude oil contaminated soil, the moisture content increases with the period of study ${ }^{(25)}$.

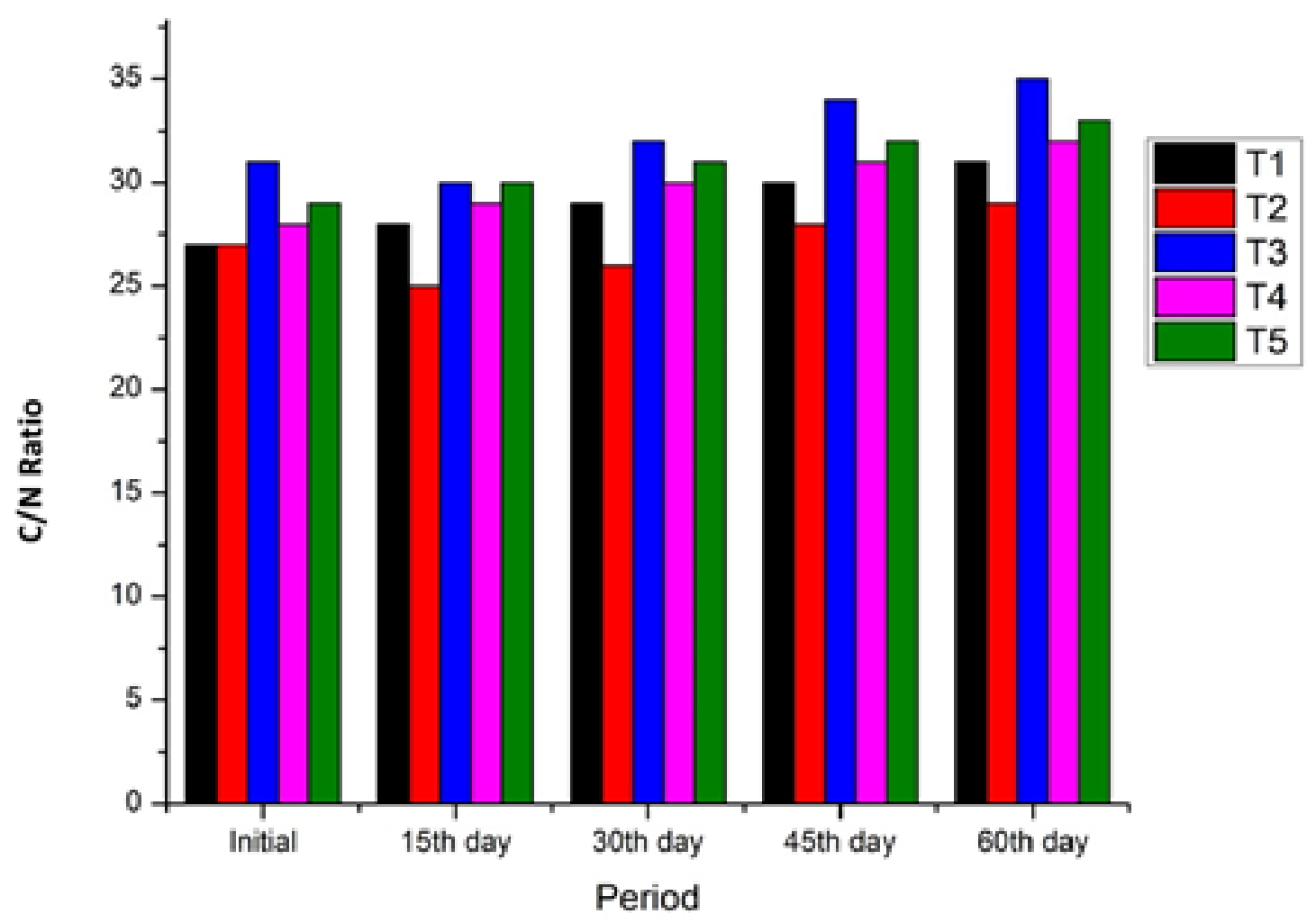

Fig 3. Effect of compost and biochar on $\mathrm{C} / \mathrm{N}$ ratio of crude oil contaminated soil planted with Cyperus rotundus(For each treatmentthree replications were maintained) (T1 - Soil (with crude oil contamination and without plant), T2 - Soil (without crude oil contamination) + plant, T3 - Soil(with crude oil contamination) + plant + biochar,T4 - Soil (with crude oil contamination) + plant + Compost, T5 - Soil (with crude oil contamination) + plant + biochar + compost $)$

\subsection{Effect on the removal of TPHs in soil}

The effect of biochar and compost on the phytoremediation of crude oil contaminated soil was determined and the results are presented in Figure 4.

The TPH content was $17.35,13.01$ and $10.25 \mathrm{mg} / \mathrm{kg}$ ( $0^{\text {th }}$ day), $17.45,10.12$ and $8.74(\mathrm{~T} 1) 17.45,10.12$ and $8.74 \mathrm{mg} / \mathrm{kg}(\mathrm{T} 2)$, $17.12,9.45$ and $5.88 \mathrm{mg} / \mathrm{kg}$ (T3), $18.11,8.55$ and $4.65 \mathrm{mg} / \mathrm{kg}(\mathrm{T} 4)$ and $18.00,6.80$ and $4.12 \mathrm{mg} / \mathrm{kg}(\mathrm{T} 5)$ at $0^{\text {th }}, 45^{\text {th }}$ and $60^{\text {th }}$ day respectively. In all the treatments, at $60^{\text {th }}$ day there was much reduction in TPH content. However, the treatment T5 (soil amended with biochar and compost recorded the least value of $4.12 \mathrm{mg} / \mathrm{kg}$ at $60^{\text {th }}$ day when compared to other treatments. 


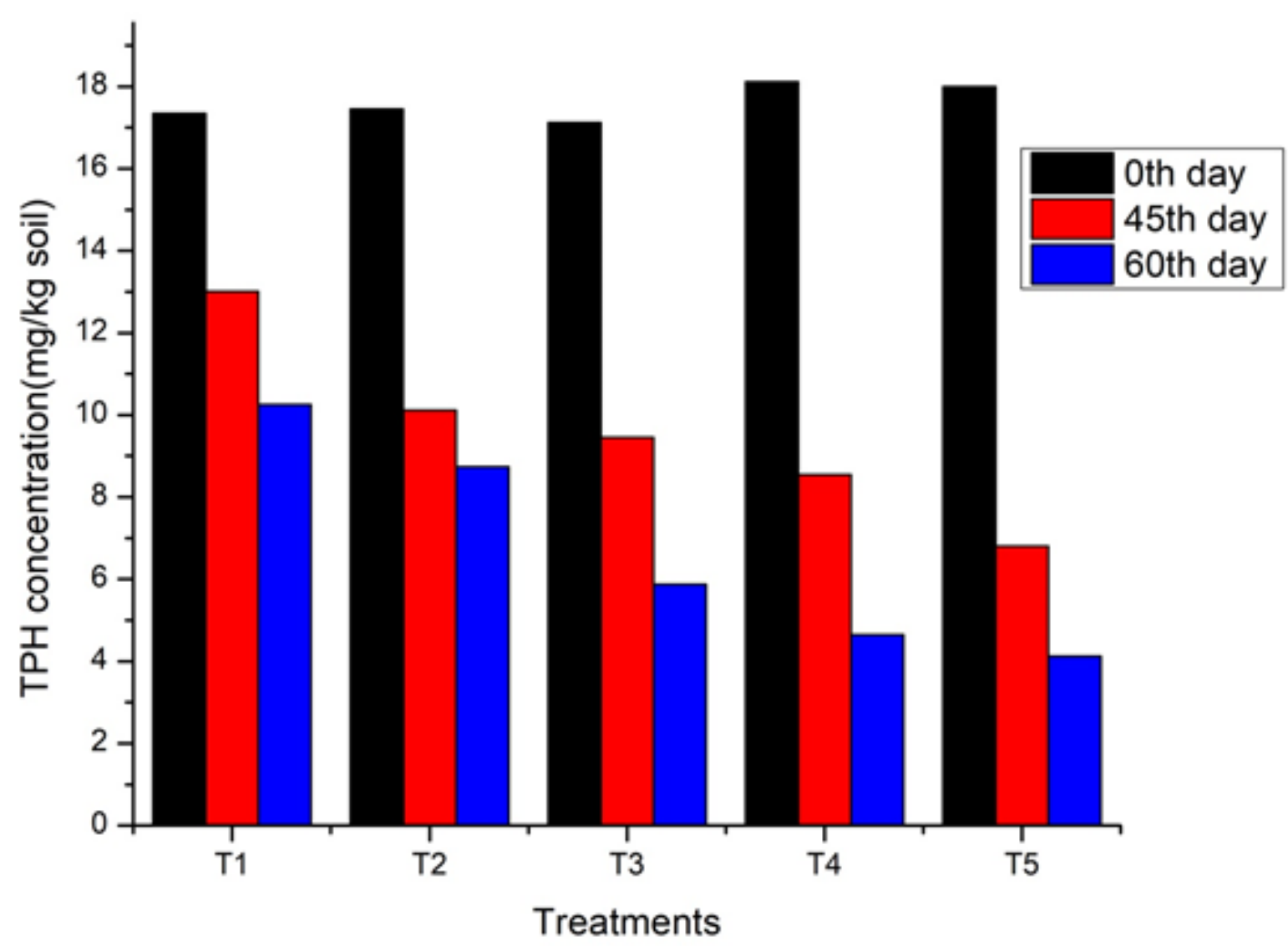

Fig 4. Effect of phytoremediation on crude oil content of soil amended with compost and biochar

Further, the \% degradation ranged from 24.5 to $62.2 \%$ for various treatments at 45 th day and 40.9 to $77.1 \%$ at 60 th day. The treatment T5 expressed the highest degradation \% of 62.2 and $77.1 \%$ respectively at 45 th and 60 th day respectively (Table 2 ).

Table 2. Growth and TPH removal rate of plants grown in crude oil contaminated soil

\begin{tabular}{|c|c|c|c|c|c|}
\hline \multirow{2}{*}{ Treatments } & \multirow{2}{*}{$\begin{array}{l}\text { Root }^{*} \\
\text { biomass(g/plant) }\end{array}$} & \multirow{2}{*}{ biomass $^{\star}(\mathrm{g} /$ plant $)$} & \multirow{2}{*}{$\begin{array}{l}\text { Shoot length }{ }^{\star} \\
(\mathrm{cm} / \text { plant })\end{array}$} & \multicolumn{2}{|c|}{ TPH removal rate (\%) } \\
\hline & & & & 45th day & 60th day \\
\hline $\mathrm{T} 1$ & No plant & 0 & 0 & 24.5 & 40.9 \\
\hline $\mathrm{T} 2$ & 0.56 & 4.25 & 52.06 & 42.1 & 49.9 \\
\hline $\mathrm{T} 3$ & 0.42 & 0.45 & 13.33 & 44.8 & 65.7 \\
\hline $\mathrm{T} 4$ & 0.54 & 3.92 & 38.14 & 52.8 & 74.3 \\
\hline T5 & 0.74 & 5.08 & 54.52 & 62.2 & 77.1 \\
\hline
\end{tabular}

* Values represent mean of three replications

Application of biochar along with chemical fertilizers to the soil in order to enhance crop growth soil is widely followed ${ }^{(28)}$. It is found that biochar amendment to soil increases the availability of phosphorus $(\mathrm{P})$, potassium $(\mathrm{K})$, sulfur $(\mathrm{S})$ and other trace elements in soil ${ }^{(29)}$. However, when biochar was applied along with rhamnolipid surfactant and nitrogen there was a significant reduction in $\mathrm{TPH}^{(30)}$. I $\mathrm{n}$ the present study, there was a slight increase in $\mathrm{pH}$ after 4 weeks. This might be due to the application 
of biochar which improves the soil quality by raising soil $\mathrm{pH}^{(31)}$. The optimum $\mathrm{C} / \mathrm{N}$ ratio for the degradation process is 15 to 30 indicating that the crude oil contaminated soil is amenable for degradation. The $\mathrm{C} / \mathrm{N}$ ratio is $>20$ in soil, indicating the consumption of nitrogen by microorganisms and enhanced degradation by microorganisms ${ }^{(32)}$. Because of the conversion of organic acids into $\mathrm{CO}_{2}$ and water during the degradation process $\mathrm{pH}$ is increased. Further, the substrate availability might be the reason for the increased $\mathrm{C} / \mathrm{N}$ ratio at the end of the experiment ${ }^{(35)}$. The compost stimulates the growth of microorganisms ${ }^{(36)}$. Similarly, the microbial population in compost enables the degradation of organic substrates ${ }^{(37)}$. Further, the TPH is made bioavailable by the compost ${ }^{(38)}$. The plant root system reduces the effects of TPH in soil, by stimulating the microorganisms in the rhizosphere ${ }^{(39,40)}$.

\subsection{Effect of biochar and compost on plant growth in crude oil contaminated soil}

The presence of low molecular weight toxic compounds in crude oil reduces the water and nutrient availability to plants causing reduced growth in crude oil contaminated soil ${ }^{(41)}$. It has been further investigated that biochar application in crude oil contaminated soil increased the TPH degradation ${ }^{(27)}$. The biochar protects the indigenous microorganisms from the toxic effect of TPH in crude oil contaminated soil by giving shelter ${ }^{(28)}$. In addition, biochar addition enhances plant growth ${ }^{(27)}$. This is achieved by the prevention of loss of nutrients by leaching in soil ${ }^{(42)}$. Furthermore, the combined effect of biochar and compost $^{(39)}$ in the degradation of TPH is better than their individual effect ${ }^{(40)}$.

Comparison of results of present work with that of previous findings is given in the following table

Table 3. Comparison of results of the present work with that of previous findings

\begin{tabular}{lll}
\hline S. No & Work done & Hydrocarbon degradation (\%) \\
\hline 1. & Soil planted with mesquite and amended with compost ${ }^{(19)}$ & 44 \\
2. & Soil amended with biochar, nitrogen and rhamnolipid surfactant in marshy soil ${ }^{(30)}$ & 80.9 \\
3. & Soil thatching grass (Hyparrhenia rufa) and amended with cow dung ${ }^{(12)}$ & 74.4 \\
4. & Nut grass (Cyperus rotendus) + compost + biochar (present study) & 77.1 \\
\hline
\end{tabular}

\section{Conclusions}

The present study revealed that the plant species nutgrass (Cyperus rotundus) could remediate the crude oil contaminated soils efficiently when amended with biochar and compost. The addition of biochar and compost could enhance the plant species to remove TPH from spoil. On the $60^{\text {th }}$ day, there was $77.1 \%$ reduction in TPH content in soil planted with nutgrass and amended with biochar and compost. Hence, the findings of the study could be employed in the field scale study to remediate crude oil contamination in soil.

\section{References}

1) Kalbuadi DN, Goenadi DH, Santi LP, Nurtjahja LR. The Potential Use of Natural Clinoptilolite Zeolite for Crude Oil Spill Removal from Sea Water. Journal of Minerals and Materials Characterization and Engineering. 2019;07(06):446-453. Available from: https://dx.doi.org/10.4236/jmmce.2019.76031.

2) Kathi S, Khan B. Phytoremediation approaches to PAH contaminated soil. Indian Journal of Science and Technology. 2011;4(1):56-63.

3) Devatha CP, Vishal AV, Rao JPC. Investigation of physical and chemical characteristics on soil due to crude oil contamination and its remediation. Applied Water Science. 2019;9(4):89-89. Available from: https://dx.doi.org/10.1007/s13201-019-0970-4.

4) Wang Q, Zhang S, Li Y, Klassen W. Potential approaches to improving biodegradation of hydrocarbons for bioremediation of crude oil pollution. Journal of Environmental Protection. 2011;2:47-55.

5) Ali N, Dashti N, Khanafer M, et al. Bioremediation of soils saturated with spilled crude oil. Scientific Reports. 2020;10. Available from: https: //doi.org/10.1038/s41598-019-57224-x.

6) Gkorezis P, Daghio M, Franzetti A, Hamme JDV, Sillen W, Vangronsveld J. The Interaction between Plants and Bacteria in the Remediation of Petroleum Hydrocarbons: An Environmental Perspective. Frontiers in Microbiology. 2016;7. Available from: https://dx.doi.org/10.3389/fmicb.2016.01836.

7) Radwan SS. Phytoremediation for oily desert soils in Advances in Applied Bioremediation. vol. 17. Berlin. Springer-Verlag. 2009;p. $279-298$.

8) Koshlaf E, Shahsavari E, Haleyur N, Osborn AM, Ball AS. Effect of biostimulation on the distribution and composition of the microbial community of a polycyclic aromatic hydrocarbon-contaminated landfill soil during bioremediation. Geoderma. 2019;338:216-225. Available from: https://dx.doi.org/10. 1016/j.geoderma.2018.12.001.

9) Annie G, Sheela AM, Ilamathi R. Fate of Crude Oil in Soil Treated with Pseudomonas putida Immobilized on Coconut Coirpith a Lowcost Biocarrier. Soil and Sediment Contamination: An International Journal. 2020;29(7):770-787. Available from: https://dx.doi.org/10.1080/15320383.2020.1771277.

10) Gong X. Remediation of weathered petroleum oil-contaminated soil using a combination of biostimulation and modified Fenton oxidation. International Biodeterioration \& Biodegradation. 2012;70:89-95.

11) Boopathy S, Appavoo MS, Radhakrishnan I. Sunflower seed husk combined with poultry droppings to degrade petroleum hydrocarbons in crude oilcontaminated soil. Environmental Engineering Research. 2020;26(5). Available from: https://dx.doi.org/10.4491/eer.2020.361. 
12) Ruley JA, Amoding A, BTumuhairwe J, Basamba TA, Opolot E, Oryem-Origa H. Enhancing the Phytoremediation of Hydrocarbon-Contaminated Soils in the Sudd Wetlands, South Sudan, Using Organic Manure. Applied and Environmental Soil Science. 2020;2020:1-8. Available from: https: //dx.doi.org/10.1155/2020/4614286.

13) Urum K, Pekdemir T, Çopur M. Surfactants treatment of crude oil contaminated soils. Journal of Colloid and Interface Science. 2004;276:456-464. Available from: https://dx.doi.org/10.1016/j.jcis.2004.03.057.

14) Beesley L, Moreno-Jiménez E, Gomez-Eyles JL. Effects of biochar and greenwaste compost amendments on mobility, bioavailability and toxicity of inorganic and organic contaminants in a multi-element polluted soil. Environmental Pollution. 2010;158(6):2282-2287. Available from: https: //dx.doi.org/10.1016/j.envpol.2010.02.003.

15) Qin G, Gong D, Fan MY. Bioremediation of petroleum-contaminated soil by biostimulation amended with biochar. International Biodeterioration \& Biodegradation. 2013;85:150-155. Available from: https://dx.doi.org/10.1016/j.ibiod.2013.07.004.

16) Basumatary B, Saikia R, Bordoloi S. Phytoremediation of crude oil contaminated soil using nut grass, Cyperus rotundus. Journal of Environmental Biology. 2012;33:891-896.

17) Basumatary R, Saikia B, Bordoloi S, Sarma HP. Phytoremediation of Petroleum Hydrocarbon (PHC) Contaminated Soil by Using Mimosa pudica L. Journal of Environmental Science and Engineering. 2014;56(3):327-332.

18) Peng S, Zhou Q, Cai Z, Zhang Z. Phytoremediationof petroleum contaminated soils by Mirabilis Jalapa L. in a greenhouse plot experiment. Journal of Hazardous Materials. 2009;168(2):1490-1496.

19) Agbogidi M, Dolor O, Okechukwu ED, M E. Evaluation of Tectona grandis (Linn.) and Gmelina arborea (Roxb.) for Phytoremediation in Crude Oil Contaminated Soils. Agriculturae Conspectus Scientificus. 2007;72(2):149-152.

20) Anih CE, Okewale A, Moses NOE. Effect of Nutrients on Bioremediation of Crude Oil-Polluted Water. American Journal of Environmental Science and Engineering. 2019;3(1). Available from: https://dx.doi.org/10.11648/j.ajese.20190301.11.

21) ASTM 2003. Standard Methods for the Examination of Water and Wastewater, Washington DC. 2003.

22) Odu CTI. Degradation and weathering of crude oil under tropical condition. In: Proceeding of an International Seminar on the Petroleum Industry and the Nigerian Environment. Warri, Nigeria. 1981.

23) Cunningham SD, Anderson TA, Schwab AP, Hsu FC. Phytoremediation of soils contaminated with organic pollutants. Advances in Agronomy. 1996;56:55114.

24) Njoku KL, Akinola MO, Oboh BO. Phytoremediation of crude oil polluted soil: Effect of cow dung augmentation on the remediation of crude oil polluted soil by Glycine max. Journal of Applied Sciences Research. 2012;8(1):277-282.

25) Schumacher BA. Methods for the Determination of Total Organic Carbon (TOC) in Soils and Sediments, US Environmental Protection Agency, Las Vegas. Las Vegas. 2002.

26) Biswas B, Qi F, Biswas J, Wijayawardena A, Khan M, Naidu R. The Fate of Chemical Pollutants with Soil Properties and Processes in the Climate Change Paradigm-A Review. Soil Systems. 2018;2(3). Available from: https://dx.doi.org/10.3390/soilsystems2030051.

27) Zhang M, Riaz M, Zhang L, El-desouki Z, Jiang C. Biochar Induces Changes to Basic Soil Properties and Bacterial Communities of Different Soils to Varying Degrees at $25 \mathrm{~mm}$ Rainfall: More Effective on Acidic Soils. Frontiers in Microbiology. 2019;10. Available from: https://dx.doi.org/10.3389/fmicb. 2019.01321.

28) Bista P, Ghimire R, Machado S, Pritchett L. Biochar Effects on Soil Properties and Wheat Biomass vary with Fertility Management. Agronomy. 2019;9(10). Available from: https://dx.doi.org/10.3390/agronomy9100623.

29) Rodriguez L, Salazar P, Preston TR. Effects of biochar and digester effluent on growth of maize in acid soils. Livestock Research for Rural Development. 2009;21(7):1-11.

30) Radwan SS, Al-Awadhi H, Sorkhoh NA, El-Nemr IM. Rhizospheric hydrocarbon-utilizing microorganisms as potential contributors to phytoremediation for the oil Kuwaiti desert. Microbiological Research. 1998;153:247-251. Available from: https://dx.doi.org/10.1016/s0944-5013(98)80007-4.

31) Sari GL, Trihadiningrum Y. Bioremediation of Petroleum Hydrocarbons in Crude Oil Contaminated Soil from Wonocolo Public Oilfields using Aerobic Composting with Yard Waste and Rumen Residue Amendments. Journal of Sustainable Development of Energy, Water and Environment Systems. 2019;7(3):482-492. Available from: https://dx.doi.org/10.13044/j.sdewes.d7.0262.

32) Ren H, Hu J, Hu Y, Yang G, Zhang Y. Divergence of compost extract and bioorganic manure effects on lucerne plant and soil. Peer J. $2017 ; 5$.

33) Gestel KV, Mergaert J, Swings J, Coosemans J, Ryckeboer J. Bioremediation of Diesel Oil-Contaminated Soil by Composting by Biowaste. Environmental Pollution. 2013;125(3):361-368.

34) Agnello AC, Bagard M, van Hullebusch ED, Esposito G, Huguenot D. Comparative bioremediation of heavy metals and petroleum hydrocarbons cocontaminated soil by natural attenuation, phytoremediation, bioaugmentation and bioaugmentation-assisted phytoremediation. Science of The Total Environment. 2016;563-564:693-703. Available from: https://dx.doi.org/10.1016/j.scitotenv.2015.10.061.

35) Shirdam R, Zand AD, Bidhendi GN, Mehrdadi N. Phytoremediation of hydrocarbon-contaminated soils with emphasis on the effect of petroleum hydrocarbons on the growth of plant species. Phytoprotection. 2009;89(1):21-29. Available from: https://dx.doi.org/10.7202/000379ar.

36) Barati M, Bakhtiari F, Mowla D, Safarzadeh S. Total petroleum hydrocarbon degradation in contaminated soil as affected by plants growth and biochar. Environmental Earth Sciences. 2017;76(20):688-688. Available from: https://dx.doi.org/10.1007/s12665-017-7017-7.

37) Tang J, Zhu W, Kookana R, Katayama A. Characteristics of biochar and its application in remediation of contaminated soil. Journal of Bioscience and Bioengineering. 2013;116(6):653-659. Available from: https://dx.doi.org/10.1016/j.jbiosc.2013.05.035.

38) Denyes MJ, Rutter A, Zeeb BA. In situ application of activated carbon and biochar to PCB-contaminated soil and the effects of mixing regime. Environmental Pollution. 2013;182:201-208. Available from: https://dx.doi.org/10.1016/j.envpol.2013.07.016.

39) Atkinson CJ, Fitzgerald JD, Hipps NA. Potential mechanisms for achieving agricultural benefits from biochar application to temperate soils: a review. Plant and Soil. 2010;337(1-2):1-18. Available from: https://dx.doi.org/10.1007/s11104-010-0464-5.

40) Al-Mansoory AF, Idris M, Abdullah SRS, Anuar N. Phytoremediation of contaminated soils containing gasoline using Ludwigia octovalvis (Jacq.) in greenhouse pots. Environmental Science and Pollution Research. 2017;24(13):11998-12008. Available from: https://dx.doi.org/10.1007/s11356-015-52615.

41) Hussain F, Hussain I, Khan AHA, Muhammad YS, Iqbal M, Soja G, et al. Combined application of biochar, compost, and bacterial consortia with Italian ryegrass enhanced phytoremediation of petroleum hydrocarbon contaminated soil. Environmental and Experimental Botany. 2018;153:80-88. Available from: https://dx.doi.org/10.1016/j.envexpbot.2018.05.012.

42) Warnock DD, Lehmann J, Kuyper TW, Rillig MC. Mycorrhizal responses to biochar in soil - concepts and mechanisms. Plant and Soil. 2007;300(1-2):9-20. Available from: https://dx.doi.org/10.1007/s11104-007-9391-5. 